\title{
ШЛЯХИ ГАРМОНІЗАЦІЇ ОСОБИСТОСТІ МАЙБУТНЬОГО ВЧИТЕЛЯ В СИСТЕМІ ПІДГОТОВКИ ДО ЗБЕРЕЖЕННЯ І ЗМІЦНЕННЯ ПРОФЕСІЙНОГО ЗДОРОВ'Я
}

\begin{abstract}
Мешко Г. М. Шляхи гармонізаиії особистості майбутнього вчителя в системі підготовки до збереження $і$ зміцнення професійного здоров'я.

У статті здійснено аналіз шляхів гармонізації особистості майбутнього вчителя у контексті підготовки його до збереження $i$ зміџнення професійного здоров'я (формування індивідуального стилю педагогічної діяльності; формування позитивного, саногенного мислення; актуалізація духовно-творчого потенціалу).

Ключові слова: гармонія $i$ дисгармонія особистості, гармонізаџія особистості майбутнього вчителя, иляхи гармонізаиії особистості.

Мешко Г. М. Пути гармонизации личности будущого учителя в системе підготовки к збережению и укреплению профессионального здоров'я.

В статье осуществлен анализ путей гармонизащии личности будущего учителя в контексте подготовки его $\kappa$ сохранению и укреплению профессионального здоровья (формирование индивидуального стиля педагогической деятельности; формирование позитивного, саногенного мышления; актуализачия духовно-творческого потенциала).

Ключевые слова: гармония и дисгармония личности, гармонизащия личности будущего учителя, пути гармонизащии личности.

Mieszko G. Ways to harmonize the individual teacher in the future to pidgotovki zberezheniyu and strengthening of occupational health.

The analysis of personality harmonization ways in future teacher in the context of her preparation to saving and improvement of professional health (the formation of individual style of pedagogical activity; the formation of positive and sanogenic thinking; actualization of spiritual and creative potential) has been carried out in the article.
\end{abstract}

Key words: harmony and disharmony of a personality, harmonization of a future teacher's personality, the ways of personality harmonization.

Постановка проблеми. В успішній педагогічній діяльності чільне місце віддано чиннику здоров'я. Професійне здоров'я вчителя $\epsilon$ необхідною передумовою компетентнісного виконання ним функціональних обов'язків $i$ водночас важливим складником його професійної придатності.

Учительство як соціальна група підкреслюється високим рівнем захворюваності, дуже низькими показниками фізичного i психічного здоров'я, підвищеним ризиком виникнення невротичних і психосоматичних розладів. У працівників системи освіти визначено найбільш високий рівень «накопичення» важких форм неврозу. Серед педагогів поширеними $\epsilon$ професійне вигорання, емоційна нестійкість, дисгармонійність особистості.

Тому актуальною проблемою психолого-педагогічної науки $\epsilon$ збереження і зміцнення здоров'я вчителів. У фокусі уваги нуковців має бути педагог з його далеким від ідеального станом здоров'я, життєвими силами, що «тануть» під час роботи 3 сучасними «особливими», «важливими», «крутими» дітьми, їх амбіційно-претензійними батьками, не завжди 
доброзичливими колегами по роботі. Нині потрібні дослідження, що стосуються профілактики, превентивних заходів, шляхів збереження i зміцнення професійного здоров'я вчителів, формування їх компетентності, стратегії здоров'язбереження, стійкості до чинників, що супроводжують педагогічну діяльність, здатності зберігати «професійну форму», загалом гармонізації їх особистості.

Для розв'язання складних питань вагоме значення має вивчення шляхів гармонізації внутрішнього світу особистості майбутнього вчителя, що сприятиме збереженню і зміцненню його здоров'я. Мета статті полягає у виявленні й аналізі шляхів гармонізації особистості майбутнього вчителя у контексті підготовки до збереження і зміцнення професійного здоров'я.

Аналіз останніх досліджень і публікацій. Аналіз проблеми гармонії і дисгармонії особистості свідчить, що цілісного вчення про це немає і його розроблення потребує зусиль представників найрізноманітніших галузей науки. 3 погляду психології, розвиток особистості передбачає наявність як гармонійних, так і дисгармонійних фаз. Ймовірність появи дисгармонійних фаз, уважає Т. Титаренко, є завжди високою. Особистісна дисгармонія визначається як «патологічне відхилення в розвитку особистості, що виникає під упливом непрямих обставин, кризових ситуацій, деструктивних конфліктів» [11].

Дисгармонійні психічні стани, спричинені переважно зовнішніми обставинами (ситуаціями стресу, фрустрації, міжособистісного конфлікту) відбиваються, в основному, на локальному самопочутті педагога й істотно не впливають на педагогічне спілкування і продуктивність педагогічної діяльності в цілому. Особистісні дисгармонії як відбиток індивідуальних історій життя за підвищеної емоційно-розумової напруги спричиняють відносно стійкі утруднення педагогічного спілкування, істотно знижують продуктивність педагогічної праці, погіршують стан професійного здоров'я [8, с. 78].

Комунікативні утруднення професійної діяльності, деструктивна взаємодія, педагогічні конфлікти розглядаються науковцями (М. Андрос, Л. Анциферова, А. Добрович, Л. Мітіна, В. Павленко, А. Реан, В. Чорнобровкін, В. Чорнобровкіна) як специфічні проблеми педагогічної праці, що складають умови для виявлення і розвитку дисгармонійних станів особистості вчителя. Невисокий рівень комунікативних умінь учнів, їх недисциплінованість, відсутність бажання вчитися, підвищена подразливість, низький рівень культури поведінки, вседозволеність, наявність у багатьох з них нервово-психічних відхилень $\epsilon$ причинами деструктивної педагогічної взаємодії. 3 іншого боку, недостатня комунікативна компетентність, незначний комунікативний потенціал, несформованість продуктивного стилю педагогічного спілкування зумовлюють низьку якість взаємин учителя з учнями, їх батьками, колегами. Особистісні дисгармонії співвідносяться зі специфічними комунікативно-поведінковими виявленнями акцентуацій темпераменту, характеру особистості як чинниками виникнення та поглиблення бар'єрів у педагогічній взаємодії.

Характеристики особистісних дисгармоній співвідносяться як 3 розладами здоров'я та аномаліями особистості (В. М'ясищев, С. Семічов, 
Є. Соколова), так i 3 характерними суперечностями психіки у межах психічної норми, психічного здоров’я (Ф. Василюк, Л. Дика, В. Мендилевич, Т. Титаренко, Т. Васильєва, А. Прохоров). Особистісні дисгармонії розглядаються в контексті «умовної норми», що містить ймовірність виникнення певної аномалії чи патології (О. Донченко, К. Леонгард, А. Мілтс, Т. Титаренко, В. Семиченко). Внутрішні дисгармонії пов'язані з упливом професійного стресу i синдрому професійного вигорання (В.Бойко, Г. Зайчикова, Л. Карамушка, Т. Ронгінська, Т. Форманюк).

Варто зазначити, що абсолютно гармонійної і незмінної особистості вчителя бути не може, оскільки дуже складний об'єкт діяльності, що постійно змінюється, різні й непередбачувані ситуації педагогічної взаємодії тощо. Спеціальні дослідження закономірностей розвитку особистісних дисгармоній свідчать про можливість їх подолання за умови врахування певних чинників. Наявність настанови на відповідні психологічні зміни - необхідна умова подолання дисгармоній. Особистісна гармонія неможлива «без задоволення від якомога повнішого розкриття власних сутнісних сил, від бачення перспектив подальшого руху вперед» [11, с. 201]. Тому вчитель має знати особливості своєї особистості, професійної діяльності, специфіку професійного розвитку і становлення, прагнути до змін, що попередить багато негативних наслідків, допоможе зберегти професійне здоров’я і довголіття.

Виклад основного матеріалу. Професійне довголіття вчителя досягається шляхом гармонізації особистості, яка розглядається як процес поступового подолання й усунення невротичних компонентів власного внутрішнього світу, підвищення рівня аутентичності, узгодженість інтегральних якостей особистості [5]. Розуміння шляхів гармонізації свого внутрішнього світу сприятиме позитивному емоційному сприйняттю себе та інших, допоможе уникати стресових і конфліктних ситуацій.

Гармонії внутрішнього світу особистості вчителя сприяють: розуміння себе, адекватна самооцінка своїх особистісних та професійно значущих рис і якостей, дій і вчинків; усвідомлення самого себе у контексті взаємин 3 собою, іншими людьми, суспільством; відповідність, зближення Я-реального та Я-ідеального, намагання бути таким, яким би хотів себе бачити; прийняття себе реального, справжнього, віра у свої можливості, значущість, привабливість, неповторність, унікальність; здатність бути самим собою у взаєминах з учнями, їх батьками, колегами по роботі, іншими людьми; осмисленість життя і власної професійної діяльності, усвідомлення та прийняття меж своєї свободи у ставленні до інших людей, навколишнього світу, відповідальність перед своїм «Я» за вибір цінностей, стратегій життя і поведінки; сформованість гнучкої Я-концепції, що зумовлює автоматично зміну поведінки у результаті перебудови уявлень про себе; здатність знаходити баланс професійного та індивідуального; прагнення до самозмін і саморозвитку, творчої самореалізації у професії.

Тому в контексті дослідження проблеми гармонізації особистості майбутніх учителів актуальними $є$ питання становлення індивідуального 
стилю діяльності і спілкування, формування позитивного, саногенного мислення, актуалізації духовно-творчого потенціалу, розв'язання яких сприятиме цілісності особистості, яка є необхідною умовою психічного, а отже і професійного здоров'я.

Індивідуальний стиль педагогічної діяльності (ICПД) - найкращий спосіб самореалізації у професії, вияву своєї неповторності й унікальності. ІСПД відіграє важливу роль у гармонізації особистості вчителя, становленні його професіоналізму, досягненні вершин «акме» у педагогічній діяльності. Стиль діяльності, який відповідає індивідуальним особливостям і специфіці професійної діяльності, є важливою передумовою становлення педагогічної майстерності, загалом задоволення суб'єкта професійної діяльності. За намагання зберігати тільки зовнішньоефективний індивідуальний стиль діяльності педагоги часто розплачуються внутрішніми дисгармоніями, проблемами психосоматичних та психовегетативних порушень [12, с. 34]. У психолого-педагогічній літературі індивідуальний стиль діяльності розглядається як форма пристосування людини 3 різними властивостями нервової системи до конкретних умов праці; спосіб реалізації потенційних можливостей особистості в діяльності; компенсація слабких індивідуальності людини сильними властивостями; виявлення глибинної стратегії індивіда i вираження його особистісних установок; зовнішне виявлення майстерності фахівця; необхідний компонент творчості [10].

У роботах багатьох авторів (А. Коротаєв, О. Лапіна, Т. Тамбовцева та інші) наголошується, що індивідуальний стиль діяльності педагога є швидше результатом саморозвитку, ніж спеціально спрямованих упливів. Але потенційні можливості майбутніх учителів можуть повною мірою виявлятися і реалізуватися за умови загальної раціональної самоорганізації та ефективного самоуправління навчальною діяльністю. Тому процес становлення індивідуального стилю діяльності буде більш ефективним, якщо організована навчально-професійна діяльність студентів поєднуватиметься із самопізнанням, самоосвітою і самовихованням.

Як свідчать результати ряду досліджень (Н. Верігіна, Ж. Ковалів, Н. Петрова, Г. Сорокіна, А. Торхова, О. Чернічкіна та інші), без спеціальної підготовки у студентів формується стереотипний стиль педагогічної діяльності і спілкування, який копіює стиль представників найближчого професійного оточення.

У майбутніх учителів можна цілеспрямовано формувати ICПД на основі розгортання всіх граней їх індивідуальності і розвитку потреби в самовиявленні через розкриття суб'єктних смислів професії. Тому на етапі професійної підготовки потрібно створити умови, що забезпечують саморозкриття індивідуальності студентів. Головне завдання навчання полягає у тому, щоб допомогти майбутнім учителям зрозуміти себе, знайти свої сильні сторони, свої проблеми, мобілізувати внутрішні сили і можливості для їх розв'язання і саморозвитку. Справжній зміст професійної підготовки, вважає О. Лапіна, полягає в тому, щоб допомогти майбутньому вчителю зорієнтуватися в типології професійної діяльності і створити умови 
для самовиявлення індивідуальності в освітньому полі професійної підготовки [4, с. 74]. Через засвоєння типового у професійній діяльності, розвиток індивідуальних потенцій та потреби у вираженні й досягненні оптимальних результатів можна привести майбутніх учителів до опанування, засвоєння особистісно значимого і професійно цінного стилю педагогічної діяльності, сформувати у них готовність до оволодіння ІСПД. Сформований індивідуальний стиль дозволяє ефективно працювати без напруження функціональних резервів, свідчить про адаптацію до професійних вимог.

Характер професійного мислення педагога - це причина його внутрішнього комфорту чи дискомфорту, успіхів чи постійних невдач у житті і професійній діяльності, професійного здоров'я чи нездоров'я. Професійне педагогічне мислення передбачає цілісне бачення педагогічної ситуації, ii системний аналіз і творчу гнучку побудову варіантів виходу з неї.

Перспективною (ідеальною), на наш погляд, є така модель професійного педагогічного мислення, в основу якої покладено реалістичне сприйняття педагогічної дійсності (прийняття педагогічної дійсності такою, якою вона є 3 усією гамою позитивних i негативних виявленняів), оптимістичне ставлення до себе та інших учасників освітнього процесу, переважання позитивних емоцій, пошук ефективних шляхів педагогічної взаємодії.

Майбутні вчителі повинні вміти свідомо саморегулювати мислення, управляти ним, тобто робити його більш організованим, більш конструктивним у розв'язанні завдань педагогічної діяльності, повинні виробляти продуктивну стратегію подолання професійних труднощів. Для того, щоб протистояти професійним труднощам, майбутнім учителям необхідно замінити негативне мислення на позитивне через пізнання себе шляхом самоспостереження, створення глибокого спокою, зосередженості й концентрації уваги на об'єктах роздуму, потрібно виробляти навички асертивної (впевненої) поведінки. Позитивне мислення допоможе робити складні, проблемні, конфліктні ситуації керованими і витрачати зусилля саме на їх розв’язання.

Щоб позитивне мислення стало стилем життя і діяльності, потрібно вивчити принципи позитивного мислення і постійно дотримуватися їх, змінити своє світосприйняття, світобачення у напрямі до оптимістичного. Зростання таких особистісних утворень, як інтелект, рефлексія, самоставлення, мотивація досягнень успіху, самоефективність сприятиме досягненню високого рівня сформованості позитивного мислення майбутніх учителів [3; 7].

Розвиток позитивного мислення майбутніх учителів передбачає формування творчого ставлення до професійної діяльності; вміння знаходити радість у досягнутому, незначних успіхах і звершеннях; свідомий контроль думок та емоцій; зміцнення віри у власні сили, можливості, успіх; формування вміння бути оптимістом в життєвих і професійних ситуаціях, навіть складних та екстремальних.

Найкоротший шлях до збереження і зміцнення професійного здоров’я, найкращий психологічний захист, спосіб гармонізації особистості педагога це оволодіння саногенним типом мислення. 
Проблемі саногенного мислення присвячено роботи багатьох вітчизняних і зарубіжних науковців (Е. Алексанровська, Р. Бернс, К. Бютнер, Т. Васильєва, Д. Джампольський, М. Джеймс, Д. Джонгвард, А. Добрович, І. Дубровіна, А. Захаров, В. Леві, В. Семке, М. Тишкова, Д. Фонтан, К. Хорні та інші). У своїх дослідженнях автори звертають увагу в основному на певні форми виявлення саногенного мислення, конкретні прийоми формування його елементів. Найбільш систематизовано і глибоко проблема саногенного мислення розроблена Ю. Орловим, який уважає, що головна роль такого типу мислення - це створення умов для досягнення цілей самовдосконалення, гармонії рис, згоди із самим собою і оточенням,позбавлення поганих звичок, керування своїми емоціями, контролю своїх потреб [6]. Це мислення зменшує внутрішній конфлікт, напруженість, попереджує захворювання, зміцнює здоров'я. Саногенне мислення сприяє оздоровленню психіки, усуненню застарілих образ, комплексів, усуває труднощі у спілкуванні, дарує успіх у діяльності і житті. Педагог із саногенном типом мислення, навпаки, уміє концентрувати увагу на позитивних явищах життя, уміє прощати образи, не тримає гніву, відкритий для дружніх стосунків з учнями, колегами по роботі, уміє жити у згоді з іншими і самим собою.

Саногенномислячому вчителеві притаманні такі риси: достатньо високий рівень загального кругозору і внутрішньої культури; здатність до рефлексії на фоні глибокого внутрішнього спокою; високий рівень зосередженості і концентрації на об'єктах роздумів; знання природи конкретних психічних станів, що дозволяє йому не ображатись на дитину, справитися з розчаруваннями у ситуаціях неуспіху, правильно зрозуміти емоційну реакцію учня (вину, сором, заздрість) і допомогти йому позбутися, переключати розум на позитивно забарвлені образи; відсутність звички очікувати неприємні ситуації, невдачі у майбутньому [1].

Характер мислення досвідченого вчителя достатньо стійкий, тому його корекція ускладнена. Вона буде ефективною на початку педагогічної кар'єри. Сприятливі умови для корекції характеру мислення є саме на етапі підготовки у вищому навчальному закладі. Адже навчання у педагогічному університеті співпадає з періодом завершення процесу становлення особистості фахівця. Уведення студента у педагогічну професію, ознайомлення з основами професійної діяльності, його перші кроки вносять поправки у світобачення майбутнього фахівця, у його місію, педагогічне кредо, мислення.

Необхідною умовою професійного здоров'я $\epsilon$ повне використання вчителем своїх талантів і здібностей, особистісного потенціалу. Актуалізуючи потенціал особистості, можна допомогти розвинути духовні сили і повірити у творчі можливості. Потенціал пов'язують із неактуалізованими у конкретний момент часу можливостями особистості, які здатні виявитися згодом при певних обставинах.

На думку багатьох науковців (Б. Ананьєв, О. Асмолов, Б. Братусь, Л. Виготський, В. Зінченко, О. Леонтьєв, С. Максименко, В. Моляко, В. Мясищев, Г. Олпорт, К. Роджерс, С. Рубінштейн, В. Слободчиков, Р. Шакуров і інші), 
особистість у процесі взаємодії 3 дійсністю $є$ насамперед нескінченне, невичерпне, потенційне за своїм характером психологічне новоутворення, якому притаманні сукупність найрізноманітніших можливостей, варіантів життєвого реагування, діяльності, поведінки і яке здійснює творчий вибір цих варіантів, прийнятих чи створених нею.

Заслуговує на увагу підхід В. Ігнатової до розуміння духовно-творчого потенціалу особистості: «Духовно-творчий потенціал особистості являє собою сукупність внутрішніх можливостей, потреб, цінностей i засобів досягнення особистістю таких станів свідомості, які гармонізують відношення особистості 3 оточуючою дійсністю, визначають інтегральний виявлення креативної і духовної складників життєдіяльності, i надають відповідної спрямованості процесу становлення особистості» [2, с. 101]. Виражається духовно-творчий потенціал в особистісних якостях, що визначають як духовно-творче становлення особистості, так і психологічне здоров'я, відкритість до всього нового, усвідомлювання, натхнення, чуйність, безкорисливість, внутрішня гармонія, любов і т.д. [там само, с. 248-249].

Актуалізація потенціалів особистості і, зокрема, духовно-творчого, веде до повноти буття людини. У повноті буття творчість із зовнішніх форм переростає у свої сутнісні буттєві форми - Життя як Творчість і Творчість як Життя. Актуалізація духовно-творчого потенціалу характеризується певними ознаками: потребою і можливістю духовно-творчої самореалізації, а також прагненням присвоювати загальнолюдські цінності [9].

Актуалізується духовно-творчий потенціал у процесі внутрішньої роботи людини над собою, над усвідомленням своїх життєвих смислів і цінностей. Актуалізація духовно-творчого потенціалу особистості стимулює життя в теперішній момент i надихає майбутнього вчителя предметно займатися власним розвитком.

Висновки. Гармонізації особистості майбутнього вчителя сприяє сформований індивідуальний стиль педагогічної діяльності, позитивне саногенне мислення, актуалізований духовно-творчий потенціал. На реалізацію окреслених аспектів гармонізації особистості майбутнього вчителя спрямована розроблена нами програма підготовки студентів до збереження i зміцнення професійного здоров'я. Втілення цієї програми дозволить знизити втрати здоров'я за час педагогічної діяльності, сприятиме професійному довголіттю. Нині констатуємо на необхідності в розробленні на державному рівні концепції професійного здоров'я (довголіття) вчителя, визначенні реальних шляхів упровадження їі в життя.

\section{Література}

1. Васильева Т. Н. Саногенное мышление учащегося, учителя / Т. Н. Васильева. Калининград : ГИПП «Янтар. сказ», 2000. - 152 с.

2. Игнатова В. В. Педагогические чинникы духовно-творческого становления личности в образовательном процессе: [монография] / В. В. Игнатова. - Красноярск : Сиб. ГПУ, 2000. - 272 с.

3. Калошин В. Ф. Як сформувати позитивне мислення / В. Ф. Калошин // Практична психологія та соціальна робота. - 1998. - № 3. - С. 23-27. 
4. Лапина О. А. Индивидуальность учителя: [учеб. пособие] / О. А. Лапина. Иркутск : Изд-во Иркутс. гос. пед. ун-та, 2006. - 133 с.

5. Митина Л. М.Концепция профессионального долголетия / Л. М. Митина // Директор школы. - 1998. - № 5. - С. 31-36.

6. Орлов Ю. М. Мышление, дарящее здоровье и успех / Ю. М. Орлов // Воспитание школьников. - 1993. - № 5-6. - С. 3-6.

7. Пил Н. В. Удивительные результаты позитивного мышления / Н.В. Пил. - Мн. : ООО «Попурри», 2003. - 320 с.

8. Савчук Н. А. Психолого-педагогічні умови корекції особистісних дисгармоній вчителів загальноосвітніх шкіл: дис... канд. психол. наук : 19.00.07 / Н. А. Савчук. - К., 2005. - 183 c.

9. Соколовская Л. Б. Актуализация духовно-творческого потенциала личности как чинника психологического здоровья молодого человека: дис... канд. психол. наук: 19.00.01 / Л. Б.Соколовская. - Красноярск, 2004. - 191 с.

10. Субботина И. В. Становление индивидуально-творческого стиля деятельности будущего учителя музыки в педагогической практике: дис. ... канд. пед. наук : 13.00.01 / И. В. Субботина. -Волгоград, 2007. - 176 с.

11. Титаренко Т. М. Життєвий світ особистості: у межах і за межами буденності / Т. М. Титаренко. - К. : Либідь, 2003. - 276 с.

12. Тригранян Р. Я. Стресс и его значение для организма / Р. Я. Тригранян / отв. ред. О. Г. Газенко. - М. : Наука, 1988. - 176 с.

Стаття надійшла до редакції 23.05.2012 p.

УДК 378. 167

3. С. Кучер, кандидат пед. наук, доиент, Криворізький педагогічний інститут ДВНЗ «Криворізький національний університет

\section{АКТИВІЗАЦІЯ ПІЗНАВАЛЬНОЇ ДІЯЛЬНОСТІ СТУДЕНТІВ ТЕХНОЛОГО-ПЕДАГОГІЧНОГО ФАКУЛЬТЕТУ ЗАСОБАМИ ПРОЕКТУВАННЯ}

Кучер 3. С. Активізація пізнавальної діяльності студентів технолого-педагогічного факультету засобами проектування.

У статті розкрито особливості активізащіі пізнавальної діяльності студентів із використання навчального проектування. Особливу увагу приділено структурним складникам проектів та обгрунтуванню педагогічних умов організації навчального проектування.

Ключові слова: пізнавальна активність, проект, навчальний проект, педагогічні умови, принципи проектування.

Кучер 3. С. Активизация познавательной деятельности студентов технологопедагогического факультета средствами проектирования.

В статье раскрыто особенности активизации познавательной деятельности студентов c использованием учебного проектирования. Особое внимание уделено структурным составляющим проектов и обоснованию педагогических условий организации учебного проектирования.

Ключевые слова: познавательная активність, проект, учебный проект, педагогические условия, принщипы проектирования.

Kucher Z. Activation of cognitive activity of students techno-pedagogical faculty of design tools.

The article revealed feature senhance the cognitive activity of students with academic planning. Particular attention is paid to the structural components of the projects and the justification of pedagogical conditions of educational design.

Key words: cognitive activity, project, schoolproject, teaching conditions, principles of design. 